\title{
New records of Lignicolous fungi from Krishna District, Andhra Pradesh, India
}

\author{
Praveen Kumar Nagadesi ${ }^{1, *}$, Jeji Bhavani ${ }^{1}$, Arun Arya ${ }^{2}$ \\ ${ }^{1}$ Department of Botany, P.G. section, Andhra Loyola College, Vijayawada - 520008, \\ Andhra Pradesh, India \\ ${ }^{2}$ Department of Botany, Faculty of Science, The Maharaja Sayajirao University of Baroda, \\ Vadodara - 390002, Gujarat, India \\ *E-mail address: nagadesipraveenkumar@yahoo.com
}

\begin{abstract}
Lignicolous fungi include many wood decay fungi. Studies on molds and decay fungi are necessary to enable us to control their growth on wood and wood products. A survey was undertaken during 2012-2013 to detect the various ligniclous fungi in Andhra Loyola College, Vijayawada and Krishna District, Andhra Pradesh. In a recent study, lignicolous fungi were collected from living trees and fallen branches from Andhra Loyola College, Vijayawada, India. On the basis of occurrence Coriolopsis aspera (Junghuhn) Teng. Fulvifomes nilgheriensis (Montagne) Bondartseva \& S. Herrera, Ganoderma australe (Fr.) Pat., G. lucidum (Curtis) P. Karsten, Hexagonia apiaria (Pers.) Fr. Phellinus linteus (Berk. \& Curt.) Teng. Trametes cingulata Berk. Hook., T. cotonea (Pat. \& Har.) Ryv. T. gibbosa (Pers.) Fr. Schizophyllum commune Fr. were reported from Krishna district for the first time. F. nilgheriensis (Montagne) Bondartseva \& S. Herrera is recorded for the first time from India. Even though being preliminary, our results point to the necessity of conservation and protection of recent fungal diversity but, in our opinion, not by making so-called "Red list of endangered species", which, due to the lack of information and very poor evidence on this group of organisms in the region under the consideration, are extremely unreliable and therefore disputable, but rather through the very short list of few not endangered species, conditionally called "White list of not endangered fungal species", if such species recently exist at all.
\end{abstract}

Keywords: New records; Lignicolous fungi; White list; Andhra Pradesh; India

\section{INTRODUCTION}

Lignicolous fungi belonging to Aphyllophorales are important in the forest ecosystem as they are active decomposers of organic matter, causing diseases in living trees of forest (Natarajan and Kolandavelu 1998). They can be a valuable resource for few pharmaceuticals, food production, bioremediation of toxic chemical spills (Kirk et al. 1992a). The Fe nanoaprticles were mycosythesized by lignicolous fungi like Pleurotus sp. Many other nanomaterials like nanoscale zeolites, metal oxides, carbon nanotubes and fibers, enzymes, bimetallic nanoparticles (BNPs), and titanium dioxide was most widely used in nanoremediation (Nagadesi et al. 2013). The list of southern Indian fungi compiled by 
Rangaswami and co-workers (1970) includes 44 polyporoid species belonging to 13 genera of which only 5 are from kerala. More recently Natarjan and Kolandavelu (1985) described some resupinate Aphyllophorales from Tamil Nadu region and this includes the poroid members Inonotus polymorphus (Rostk.) Pilat, Phellinus allardii (Bres.) Ryv., P. umbrinellus (Bers.) Ryv. and P. purpureo-gilvus (Petch) Ryv. the most recent work on polyporaceae of india is by Roy and De (1996) which gives a record of only six polypores from Kerala.

The Central Indian fungus was first reported by Sabnis and Amin (1992) from Sardar Sarovar Environs in Gujarat. Bakshi (1971) reported Polyporus luteo-umbrinus Romell on ground attached to buried wood or root and dead leaves of Heritiera minor in Baroda. Arya (2004) reported Ganoderma lucidum (Fr.) Ryv., Phellinus nilgheriensis (Mont) Cunn, Trametes cingulata Fr. and T. varians Van der Bij. from Baroda and Shoolpaneshwar wildlife sanctuary. Arya et al. (2008) reported that Lenzites stereoides was recorded for the first time on $T$. grandis. Two other basidiomycetous fungi $N$. floccosa and $C$. aspera are reported for the first time from India by them. The wood deteriorating fungi were collected from Ratanmahal Wildlife Sanctuary (RWLS) during October 2006 to January 2011. More than 50 samples of basidiocarps were collected in which 36 samples were identified, Aurificaria indica var. indica var. nov, and Microporus affinis var. glabriceps var. nov are new varieties to India and four members i.e. Fomitopsis cupreorosea (Berkeley) J. Carranza \& Gilbertson, Ganoderma curtisii (Berk.) Murrill., Microporus alboater (Hnennings) Kuntze and Phellinus shaferi (Murr.) Ryv. are new reports for India (Nagadesi and Arya 2012) N. floccosus causing heart rot was recorded in living trees of Alianthus excelsa for the first time. The cultural characters of $N$. floccosus were described for the first time. Heart rot fungus i.e. $N$. floccosus decayed mostly heartwood of living tree. It colonized in the central portion of tree and begins decaying of wood which ultimately lead to death of $A$. excelsa tree was recognized for the first time (Nagadesi and Arya 2014). Timer decay is caused by primarily enzymatic activities of microorganisms. For the first time fungal diversity of timber degrading fungi was studied in Gujarat, India. The teak wood present in sawmills was infected with 14 types of lignicolous fungi in which $L$. sterioides and $T$. versicolor damaged the wood severely was reported for the first time. (Nagadesi and Arya 2014).

In India Phellinus was studied by Bagchee (1950, 1961), Bakshi $(1955,1976)$, Ganesh and Leelavathy (1986), Natarajan and Kolanduvelu (1998), Roy (1979), Sharma (1995, 1999a) Singh (1966) and Thind and Dhanda (1980a), Three hundred and sixty seven Phellinus spp. have been reported in the CBS (http://www.punenvis.nic.in/bd list.htm). Fifty-three species have been already reported from India (Sharma 1999a). Eighteen species have been reported from Kerala (Ganesh and Leelavathy, 1986). A few species of Phellinus was reported from Gujarat i.e. Phellinus nilgheriensis (Mont.) Cunn. by Arya (2004).

\section{MATERIALS AND METHODS}

\section{1. Survey of Krishna District}

Vijayawada is famous for educational facilities. By 1950, 5 degree colleges were established in Vijayawada. It is presently a hub of residential Schools, Corporate Junior colleges. Presently we have more than 20 engineering colleges and 4 medical colleges with in radius of $15 \mathrm{~km}$ from Vijayawada. It is also a city known for its busy commercial activity. It is called as the Venice of the east. River Krishna flows through the city. It has the privilege of having the famous Krishna dam built across the river in the year 1854 by captain Orr and Sir 
Arthur Cotton. The city has several historical monuments such as Mughalrajpuram cave, Akkanna madanna cave, Buddha and Jain monuments, Bhavani islands Gunadala Mary Matha shrine, and the famous Undavalli caves are located on the south bank of the river.

Andhra Loyola College was founded in December 1953 and established in 1954. Today it is one of the premier institutions of higher learning in southern India. It spread over a sprawling campus of 100 acres with gothic structures in the heart of Vijayawada city. The different plants like Peltophorum, Ficus bengalensis Dalbergia sisso, Polyalthia longifolia, P. pendula, Eucalyptus, Syzygium commune and Albezia lebica were planted at the starting of the college so the age of the plants is around 50 years. Recently teak plantation is done which is having the age around 2 to 3 years. Different medicinal plants are preserved in herbal garden and Santalam album is also present in Botanical garden maintained by the college. Different lignicolous fungi were found associated 50 years of age old plants so the fungi were collected and identified and their taxonomical details are described.

\section{2. Identification Of Fungi}

Materials were collected in clean polythene bags from different locations and brought to the laboratory. The specimens were examined for external and internal morphology. For external morphology the materials was observed for colour, texture, type of attachment to host, pore morphology, dissepiments characters; margin, hymenial and pileal surface of basidiocarps and for internal morphology (presence/absence of structures, dimensions, vegetative and reproductive characters (Ryvarden 1991). To observe basidia and setae, free hand sections were taken. For the clear observation of setae, trammel setae and setal hyphae, lacto phenol cotton blue was used as staining and mounting medium. For amyloid and nonamyloid reaction, spores were treated with iodine solution which turns blue. Xanthochoric reaction was also tested using potassium hydroxide solution. Microphotographs were taken by using Lyica trinocular microscope with canon digital camera attachment.

The measurements of hyphae, basidia, cystidia, setae, spores and cutis elements etc were taken by using objective micrometer. Dimensions of microscopic characters are given in micrometer. The various details of specimens were compared with Hymenochaetaceae of India (Sharma 1995) Indian Polyporaceae (Bakshi 1971), CBS Aphyllophorales database, New Zealand Fungi database, and Species Fungorum, (Sep. 2005). Certain specimens were sent to the Forest Research Institute, Dehradhun for final confirmation. These fungi were kept in fungal collection of Botany Department of Andhra Loyola College, Vijaywada, Krishna District, Andhra Pradesh, India.

\section{RESULTS AND DISCUSSIONS}

\section{1. Coriolopsis aspera (Junghuhn) Teng. 1963, Chung- Kuo Ti Chen-Chun: 759}

Basionym: Trametes aspera, Polyporus asper Jungh

Fruit body (Fig. III. A) annual, imbricate forming a cluster on branches of Casurina. Basidiocarp $6 \mathrm{~cm}$ long and $5.5 \mathrm{~cm}$ wide $0.5 \mathrm{~cm}$ thick. Yellowish to brown in colour, upper pileus hairy, margin rounded but not completely smooth, it is deflexed. Pore surface darker than context, pore round 3-4 per mm, fungal tissue turning black in $\mathrm{KOH}$. Body shows very light coloured growth zones (Fig. III. A). Hyphal system trimitic, binding hyphae irregular in outline, strongly branched. Spores cylindrical $9-10 \times 3-4.4 \mu \mathrm{m}$, hyaline, thin walled and non-amyloid. 
Habitat: Found on the dead wood of Casurina equsitifolia, from Ramarajaya nagar, Krishna district, Andhra Pradesh, collected by N. Praveen Kumar, Accession no: ALC 7. 810-2012.

\section{2. Fulvifomes nilgheriensis (Montagne) Bondartseva \& S. Herrera Mikol. Fitopatol. 26(1): 131992}

BASIONYM: Polyporus nilgheriensis Montagne Ann. Sci. Nat., Bot., II 18: 22, 1842

Sporophore sessile, fan shaped, hard on drying $5.5-6.0 \times 3.5-4.5 \times 0.5 \mathrm{~cm}$, upper surface yellowish brown in young and black in old, soft, concentrically zoned, rugulose, context deep brown and shining ( Fig. II. C.), lower surface yellowish brown, pores very minute, uniform, almost round, 110-130 $\mu \mathrm{m}$ wide, dissepiments 35-70 $\mu \mathrm{m}$ thick (Fig. II. D.). Spores $4-4.5$ x $3.3-3.5 \mu \mathrm{m}$, yellow brown, ellipsoid, obtuse, smooth, very abundant. Setae 30-45 x $812 \mu \mathrm{m}$, ventricose, very thick-walled, acute, straight or curved, very sparse. Hyphal system dimitic, without clamps; skeletal hyphae in the flesh 3.5-5.5 (-6) $\mu \mathrm{m}$ wide, rather distantly septate, with yellow brown walls $-1 \mu \mathrm{m}$ thick, unlimited, here and there branched, a thin-walled generative hyphae 2-3 $\mu \mathrm{m}$ wide, not with Y-branching; generative hyphae 1.5-3.5 $\mu \mathrm{m}$ wide; dissepiments similar, with skeletals $2.5-4 \mu \mathrm{m}$ wide, not agglutinated. Crust in the flesh at the base of the tomentum 20-30 $\mu$ m thick at c. $10 \mathrm{~mm}$ from the margin of the pileus.

Habitat: Found on the living trees of Peltophorum, from Andhra Loyola college, Krishna district, Andhra Pradesh, collected by A.J. Bhavani, Accession no: ALC 6. 28-92012.

The hyphal construction is that which is usually described as Inonotus. According to Ryvarden and Johansen (1980), the species lacks setae and had, in this way, been confused by Cunningham with $P$. extensus. However, I certainly found typical setae, though they were very sparse, and they were considerably larger than in $P$. extensus $(10-25 \times 5-9 \mu \mathrm{m})$, as given by Ryvarden (2004).

Because of the uncertainties about the living features of the fungus, I describe the following two varieties which, microscopically, can scarcely be separated as species. They agree in the sessile tomentose pileus with a crustaceous layer at the base of the tomentum, the short tubes, small pores, small yellow aguttate spores, the very sparse and more or less curved setae, the hyphal system dl to d2 without Y-branching of the skeletals, and the nonagglutinate dissepiments. Thus, this species combines the characters of Inonotus, Phellinus and Phylloporia. An Indian collection, namely Carmichael Medical College n. 1228, from the neighbourhood of Calcutta, determined as Polyporus nilgheriensis by S.R. Bose, may be Coltricia sideroides or an unnamed species of that genus. It has a matt pleuropodal pileus without a crust, pores 130-160 $\mu \mathrm{m}$ wide, yellow brown spores 55.5 x $4.5 \mu \mathrm{m}$, coltricioid hyphae, and more or less agglutinated dissepiments.

\section{3. Ganoderma australe (Fr.) Pat. Bull. Soc. Mycol. France 5: 71, 1889}

Basionym: Polyporus australis Fr. Elenchus Fungorum 1: 108, 1828

Fomes australis (Fr.) Cke., Grevillea 14: 18, 1885.

Fomes brownii Murr., Mycologia 7:215, 1915.

Ganoderma applanatum var. brownii (Murr.) Humph. \& Leus., Philipp. J. Sci. 45: 531, 1931.

Hymenophore perennial, solitary, firm and woody, attached by a lateral base. Pilei applanate, 7-30 $\mathrm{cm}$ wide, $5-20 \mathrm{~cm}$ radius, $2-11 \mathrm{~cm}$ thick; pileus surface brown (Fig. I C.), concentrically sulcate; cortex 1-8 mm thick, black, shining, hard, brittle, of densely 
intertwined cemented hyphae, rimose, fissures developing both laterally and vertically; margin obtuse, even, concolorous; hymenial surface grayish brown, even, with a sterile border 2-10 $\mathrm{mm}$ wide. Pores vaguely stratose, 2-7 $\mathrm{mm}$ long in each layer, 3-4 per $\mathrm{mm}, 150$ $300 \mu \mathrm{m}$ diameter; dissepiments 100-150 $\mu \mathrm{m}$ thick, equal, apices finely velutinate (Fig. I. D.). Context occupying about one-third of the pilei, chocolate, zoned, of densely intertwined hyphae; skeletal hyphae to $6 \mu \mathrm{m}$ diameter, walls thickened, fuscous; binding hyphae to $6 \mu \mathrm{m}$ diameter, freely branched, aseptate, lumena almost capillary, walls fuscous; generative hyphae to $3 \mu \mathrm{m}$ diameter, branched, septate, walls $0.2 \mu \mathrm{m}$ thick, hyaline. Hymenial layer to $20 \mu \mathrm{m}$ deep, a close palisade of basidia and paraphyses, soon collapsing. Basidia clavate, 10$14 \times 9-11 \mu \mathrm{m}$, bearing 2-4 spores; sterigmata arcuate, to $4 \mu \mathrm{m}$ long. Paraphyses clavate, $8-12$ x 7-10 $\mu \mathrm{m}$. Spores elliptical or ovate, 11-13 x 6-9 $\mu \mathrm{m}$, walls coarsely punctate, appearing verruculose with spines often in striae, to $2 \mu \mathrm{m}$ thick, apices sometimes truncate, yellowbrown.

Habitat: Found on the living trees of Syzygium cumini, from Andhra Loyola College, Krishna district, Andhra Pradesh, collected by N. Praveen Kumar, Accession no: ALC 2. $27-$ 9-2012.

It was found on deciduous wood of Pantropical and common in East Africa. Because it has long-lived and large fruit bodies it is conspicuous and is frequently collected by Ryvarden and Johansen in 1980. Bark and decorticated wood of dead standing trunks and stumps, associated with a white rot. Found in East and West Indies, North and South America, Australia, Tasmania, New Zealand (Cunningham 1965).

\section{4. Ganoderma lucidum (Curtis) P. Karsten Rev. Mycol. (Toulouse) 3(9): 17, 1881}

BASIONYM: Boletus rugosus Jacquin, Flora Austriaca 2: 44, f. 169, 1774

= Boletus lucidus W. Curtis, Flora londinensis f. 4, pl. 224, 1781 (typus iconog.).

= Polyporus lucidus Fr.. Syst. Mycol. 1: 353, 1821.

= Ganoderma tsugae Murrill, Bull. Torrey bot. Cl. 29: 601, 1902.

Basidiocarp (basidioma) annual, long mesopode in buried wood, generally thick, up to $20 \mathrm{~mm}$, pileus subplane, up to $160 \mathrm{~mm}$ across; stipe up to $100-120 \mathrm{~mm}$ long, $10-30 \mathrm{~mm}$ thick; upper surface and stipe shiny, lacquered, blackish-brown, irregularly humped (Fig. I. E.); margin and pore surface white when growing, tawny with age. Cutis thin, a fraction of $1 \mathrm{~mm}$, context from russet near the tube layer to white for the major part (Fig. I. F.); context white with concentric lines of various shades; tubes monolayered, up to $15 \mathrm{~mm}$ long, russet, concolorous with lower part of context. the melanoid substances are easily saponifed by $\mathrm{KOH}$; Skeletal Hyphae brown in the coloured parts of the context, nearly hyaline or hyaline close to cutis, 3-4 $\mu \mathrm{m}$ wide, sparsely ramified, subparallel to intertwining, especially in the less coloured parts of the context, no binding hyphae. Pores circular to irregular, 100-430 $\mu \mathrm{m}$ diam., with dissepiments usually relatively thin, 10-320 $\mu \mathrm{m}$ thick; distance between axes of pores $\pm 260 \mu \mathrm{m}$. Basidiospores ovoid, double-walled, epispore thin, ovoid, hyaline; endospore thick, ovoid, with usually a small part of the apex brown, bearing relatively few long and thick echinules that support the epispore, $8-13 \times 5,5-9 \mu \mathrm{m}$.

Habitat: Found on the living trees of Syzygium cumini from Andhra Loyola College, Krishna district, Andhra Pradesh, collected by N. Praveen Kumar, Accession no: ALC 2. 279-2012.

It was found on Angiosperms and Gymnosperms tress like Quercus sp., Quercus Ilex, Ligustrum vulgare, Carpinus betulus, Fagus sylvatica, Corylus avellana, Populus alba, Prunus insititia, Picea sp., Taxus sp., Larix sp., and Abies sp. It causes Butt rot and lethal root disease of many tree species. It was observed throughout the temperate zones of the northern 
hemisphere, from the Pacific shores of the USA and Canada, through temperate Europe to the Pacific shores of Asia and Japan. Also in the mountains of Central Africa above the $1500 \mathrm{~m}$ level (Steyaert, 1975).

\section{5. Hexagonia apiaria (Pers.) Fr. 1838, Epicrisis Systematis Mycologici: 498}

Basyonym: Polyporus apiarius Persoon 1827.

Fruit body annual, solitary, sessile with smooth margins, $2.8 \times 1.1 \mathrm{~cm}$ and $4 \mathrm{~mm}$ thick, corky. Pileus circular, light brown to dark cinnamon coloured (Fig. III. B). Pores hexagonal, larger in the centre (Fig. III. C). Hyphal system trimitic, generative hyphae hyaline, septate and with clamp connections, $1.5-2.2 \mu \mathrm{m}$ wide. Binding hyphae thick walled, skeletal hyphae dominating in the basidiocarp, yellowish to pale rusty brown, unbranched. Basidia clavate, cystidiod hyphae projecting into hymenium. Basidiospores not seen.

Habitat: Found on the living trees and fallen branches of Peltophorum from Andhra Loyola College, Krishna district, Andhra Pradesh, collected by N. Praveen Kumar, Accession no: ALC 15. 27-9-2012.

\section{6. Phellinus linteus (Berk. \& Curt.) Teng. Fungi of China p. 467, 1964}

BASIONYM: Polyporus linteus Berk. \& Curt., Proc. Amer. Acad. (Boston) 4:122, $1860(\mathrm{~K} ;)$.

- Pyropolyporus yucatanensis Murr. Torrey Bot. Club Bul. 30:119, 1903.

Fruitbody perennial, solitary, pileate broadly to more narrowly attached, rigid and woody hard when dry. Pileus dimidiate, ungulate, up to $10 \mathrm{~cm}$ wide, $18 \mathrm{~cm}$ broad and $6 \mathrm{~cm}$ thick near the base, upper surface first finely velvety tomentose, dark reddish-brown, concentrically zoned and sulcate, later glabrous. Margin thick and entire, usually pale (Fig. I. A). Pore layer dark reddish-brown, round, 6-8 per $\mathrm{mm}$, dissepiments fairly thin and entire, tubes greyish brown, distinctly stratified, each layer up to $15 \mathrm{~mm}$ thick, separated by a thin context layer (Fig. I. B). Context reddish-brown, fibrous shiny, darkening in $\mathrm{KOH}$, up to 20 $\mathrm{mm}$ thick. Hyphal system dimitic, generative hyphae hyaline, thin walled, branched, 2-3.5 $\mu \mathrm{m}$ wide, skeletal hyphae yellowish, thick-walled, unbranched, 4-5.5 $\mu \mathrm{m}$ wide. Setae ventricose, dark brown, variable, mostly 15-30 $\mu \mathrm{m}$ long, but a few also measured up to 35 $\mu \mathrm{m}, 4-9 \mu \mathrm{m}$ wide, usually abundantly present. Spores globose, rusty brown in maturity, 4-5.5 x 3.5-5 $\mu \mathrm{m}$, slightly thick-walled.

Habitat: Found on the living trees of Peltophorum from Andhra Loyola College, Krishna district, Andhra Pradesh, collected by N. Praveen Kumar, Accession no: ALC 1. 279-2012.

Found on angiosperms and observed in pantropical. According to Lowe (1957) widespread in tropical America. In Africa we have examined specimens from Ethiopia, Tanzania, Kenya and Zaire besides one collection from India (Punjab Univ. Herb. 6168).

\section{7. Trametes cingulata Berk. Hook. J. Bot. 6: 164, 1854}

Fruitbody perennial, solitary, fused laterally, connate rows of fruitbodies, applanate, semicircular with a contracted base, up to $8 \mathrm{~cm}$ wide and $9 \mathrm{~cm}$ long, 2-10 mm thick at the base, coriaceous when dry. Pileus first finely velvety, but soon becoming glabrous, semiglossy, whitish, concentric zones which may be slightly sulcate, margin usually perisistently whitish, thin, round, entire and only slightly lobed. Pore surface flat, ochraceous, shiny, pores round and regular, 4-6 per mm, fairly thick-walled, tubes up to $4 \mathrm{~mm}$ deep, nonstratified. Context cream, 1-4 mm thck, yellow in $\mathrm{KOH}$, the upper greyish layer very thin and 
not present as a distinct cuticle (Fig. II. A). Hyphal system trimitic, generative hyphae clamped, hyaline and thick-walled, 1-3 $\mu \mathrm{m}$ in diameter, skeletal hyphae abundant in the whole fruitbody, yellow and thick walled, in the context especially golden and solid, 3-6 $\mu \mathrm{m}$ wide, often with simple secondary septa, binding hyphae also frequent, thick-walled to almost solid in the context, hyaline to yellow, 1-4 $\mu \mathrm{m}$ wide, tapering towards the ends, slightly irregular and moderately branched. Cystidia none. Spores broadly ellipsoid, 5-6.5 x 3.5-4 $\mu \mathrm{m}$, smooth, hyaline and non-amyloid.

Habitat: Found on the dead wood of Casurina equsitifolia, from Ramarajaya nagar, Krishna district, Andhra Pradesh, collected by N. Praveen Kumar, Accession no: ALC 4. 210-2012.

Found on deciduous wood, often on decorticated trunks in open and sunny localities. Observed throughout Asia and Africa where it is common in the continent south of Sahara. T. cingulata is usually easy to recognize because of the sooty black colours on the glabrous, often concentrically sulcate, pileus. There is no cuticle and the colour is restricted just to a somewhat crumbly layer of hyphae. The spores obtained from our sporeprints are slightly larger than those reported by Westhuizen (op.cit.) Ryvarden and Johansen 1980.

\section{8. Trametes cotonea (Pat. \& Har.) Ryv. Norw. J. Bot. 19(3-4): 236, 1972}

BASIONYM:- Polyporus cotoneus Pat. \& Har. Bull. Soc. Mycol. Fr. 9: 208, 1893.

Fruitbody annual, mostly resupinate effused with elongated pilei along the upper edge single or as fused rows of semicircular pilei, broadly attached without decurrent resupinate parts, pilei often imbricate, single pilei up to $6 \mathrm{~cm}$ wide and $5-6 \mathrm{~cm}$ long, papery thin and flexible, up to $3 \mathrm{~mm}$ thick at the base. Pileus flat, undulating, creamish white, first finely velutinate, but soon glabrous and dull, usually concentrically sulcate in variable zones, often also radially furrowed, striate, Margin thin, acute and wavy. Pore surface cream, pores first round and thick-walled, 3-4 per mm, often slightly radially elongated, dissepiments entire, tubes up to $2 \mathrm{~mm}$ long, sterile margin 1-4 mm broad (Fig. II. B). Context cream, cottony, 0.5$1 \mathrm{~mm}$ thick. Hyphal system trimitic, generative hyphae clamped, hyaline and thin-walled, 1-3 $\mu \mathrm{m}$ in diameter, often strongly branched in the hymenium, up to $4 \mu \mathrm{m}$ wide in the pilear tomentum. Skeletal hyphae abundant, pale yellow, moderately thick-walled in younger parts, almost solid in older parts, 2-7 $\mu \mathrm{m}$ in diameter, often with simple secondary septa. Binding hyphae abundant, pale yellow, thick-walled, moderately branched, 1-4 $\mu \mathrm{m}$ wide. Context and pilear tomentum are dominated by solid, yellow skeletal hyphae. Cystidia none, but cystidiols projecting above the hymenium may be present. Spores cylindrical, hyaline, smooth and thinwalled, 7-10 x 2.5-3.5 $\mu \mathrm{m}$, non-amyloid, difficult to find in dried specimens.

Habitat: Found on the dead wood of Prosopis julifera, from Krishna district, Andhra Pradesh, collected by N. Praveen Kumar, Accession no: ALC 8. 30-9-2012

Found on dead wood in Afro-Asian species, quite common in Africa from Ghana and Sierra Leone in the west to Ethiopia in the north and through Kenya, Tanzania, Uganda, Zambia and Malawi. Further from Mauritius, Reunion and Socotra in the Indian Ocean, in Asia we have only seen it in Thailand. Quite easy to recognize because of the thin and flexible fruit bodies with an even whitish-pale ochraceous colour, mostly widely effused with small pilei and small pores. Macroscopically, T. membranaceus (Fr.) Ryv. (often cited as Polyporus tenuis) from N. America is similar, but has much shorter spores (4.5-6 $\mu \mathrm{m}$ long) Ryvarden and Johansen 1980. 


\section{9. Trametes gibbosa (Pers.) Fr. 1838, Epicrisis Systematis Mycologici: 492}

Synonym: Merulius gibbosus (Pers.) Fr.

Basidiocarp was annual, tough, white rotting, shelf or hoof shaped, $5 \times 8 \times 0.9 \mathrm{~cm}$ thick, upper surface cream to brownish, concentrically zoned, smooth (Fig. III. D). lower surface brownish, Pores small, round, 6-8 per mm (Fig. III. E), fusiform simple cystidia present, spores ellipsoid to cylindrical, colourless, 7-9 $\mu \mathrm{m}$ in length.

Habitat: Found on the dead wood of Peltophorum, from Krishna district, Andhra Pradesh, collected by N. Praveen Kumar, Accession no: ALC 17. 2-10-2012.

\section{10. Schizophyllum commune Fr.}

The fruiting bodies were scattered or clustered on hardwood logs and branches. Fruiting body was gymnocarpous with the sporiferous part of the fruit body restricted or limited only to the underside of the cap. The hymenophore was confined to the lower side. The fruiting body was 1-4 cm wide and laterally attached to substratum, stipeless or irregular to shell shaped. The upper surface was covered with small white to grayish hairs. Hymenophore was gilled. They were distinct on the under surface, folded and split down the middle. Hence, these fungi were also designated as split fungi or split gilled fungi. The split was shallow and resembled a groove. Fruiting bodies were shrivelled in dry weather and appeared light grey to brown. The marginal proliferation was very distinctly noticed in the collected sample.

\section{Illustration of figures}

Figure I. A). Upper surface of Phellinus linteus, B). Lower surface of $P$. linteus

C). Upper surface of Ganoderma australe, D). Lower surface of G. australe

E). Upper surface of G. lucidum, F). Lower surface of G. lucidum

Figure II. A).sporophores of Trametes cingulata, B) Upper and pore surface of T. cotonea C). Upper surface of Fulvifomes nilgheriensis D). Lower surface of F. nilgheriensis

Figure III. A). sporophore of Coriolopsis aspera, B). Upper surface of Hexagonia apiaria C). Lower surface of Hexagonia apiaria D). Upper surface of trametes gibbosa E). Lower surface of $T$. gibbosa

Figure I

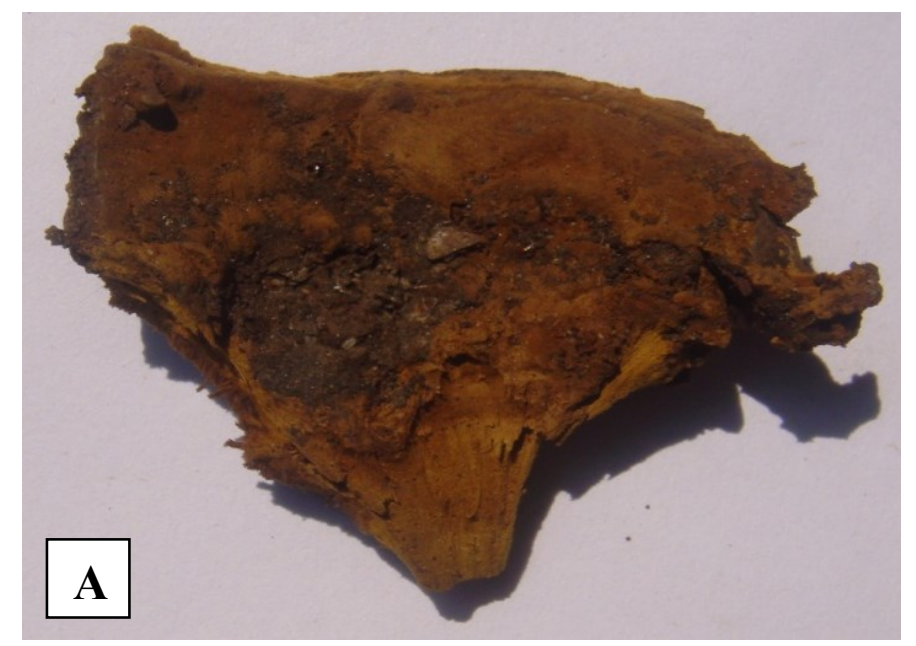



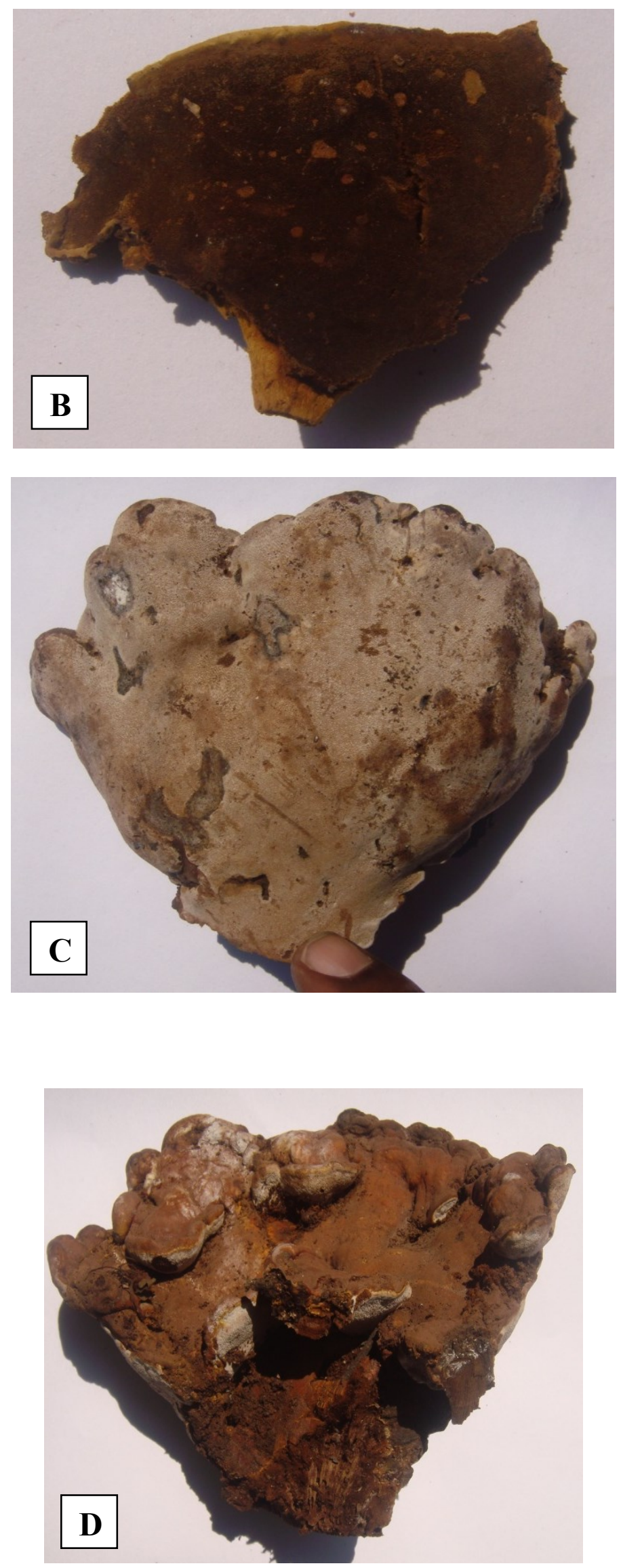

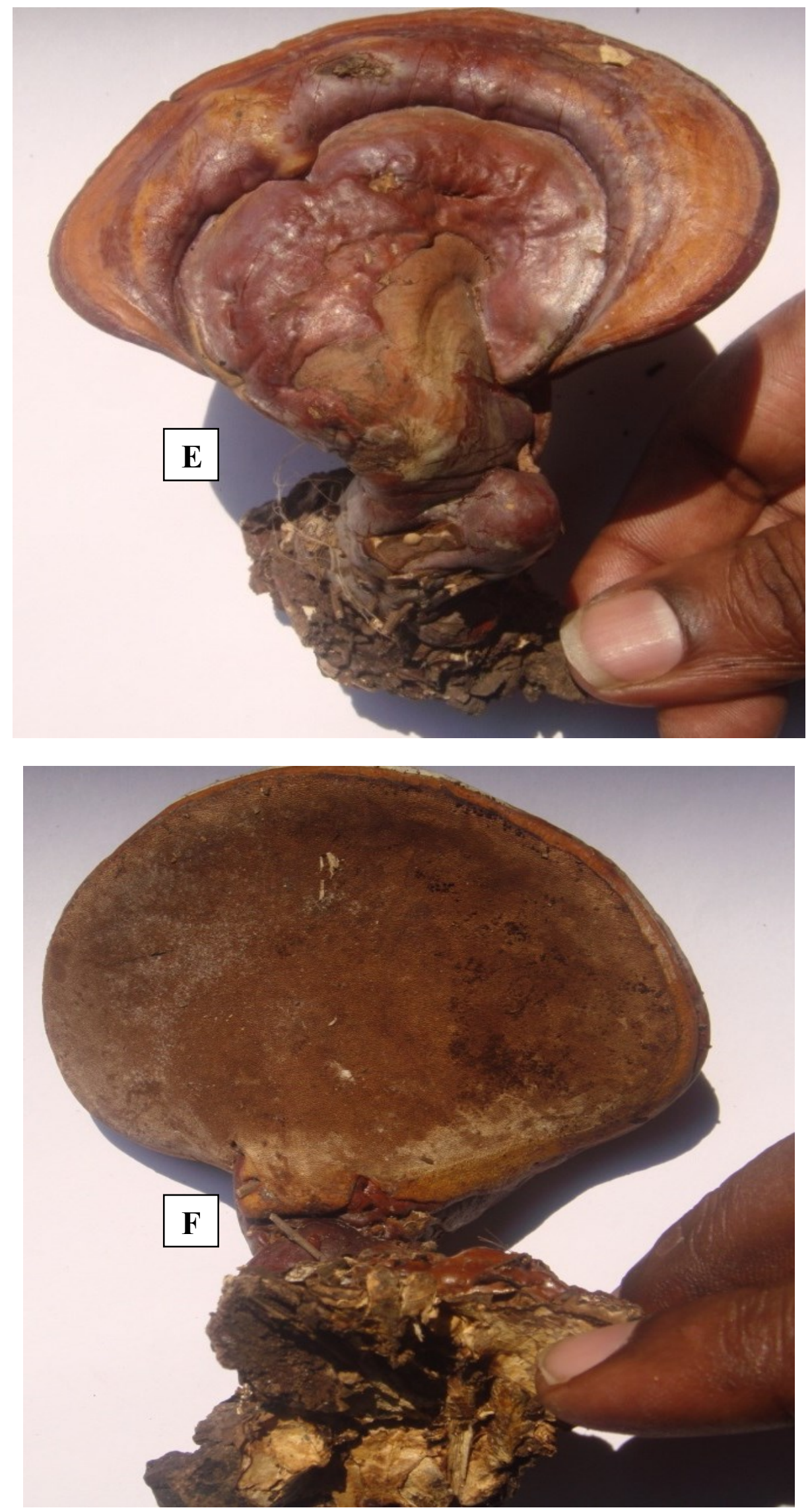
Figure II
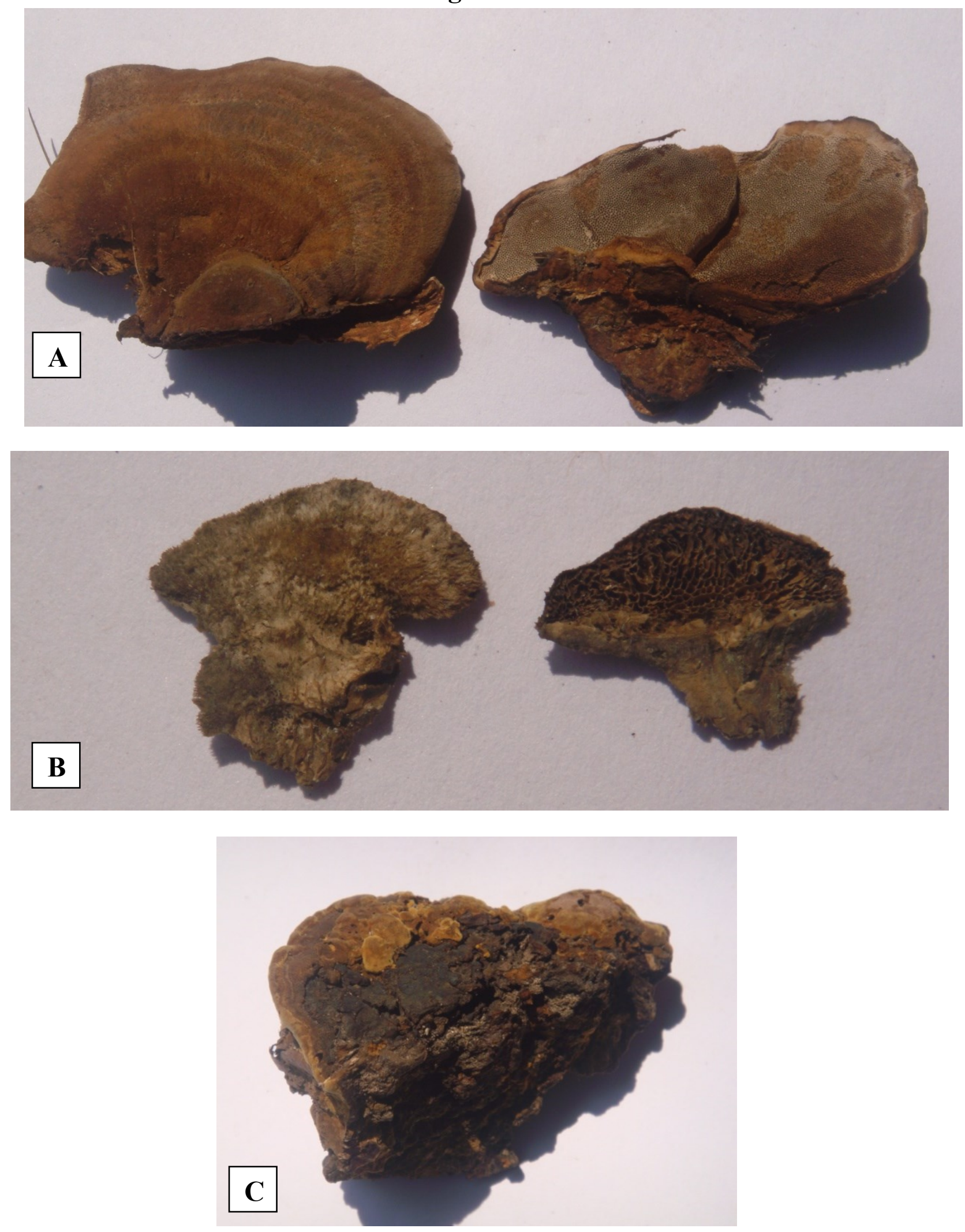


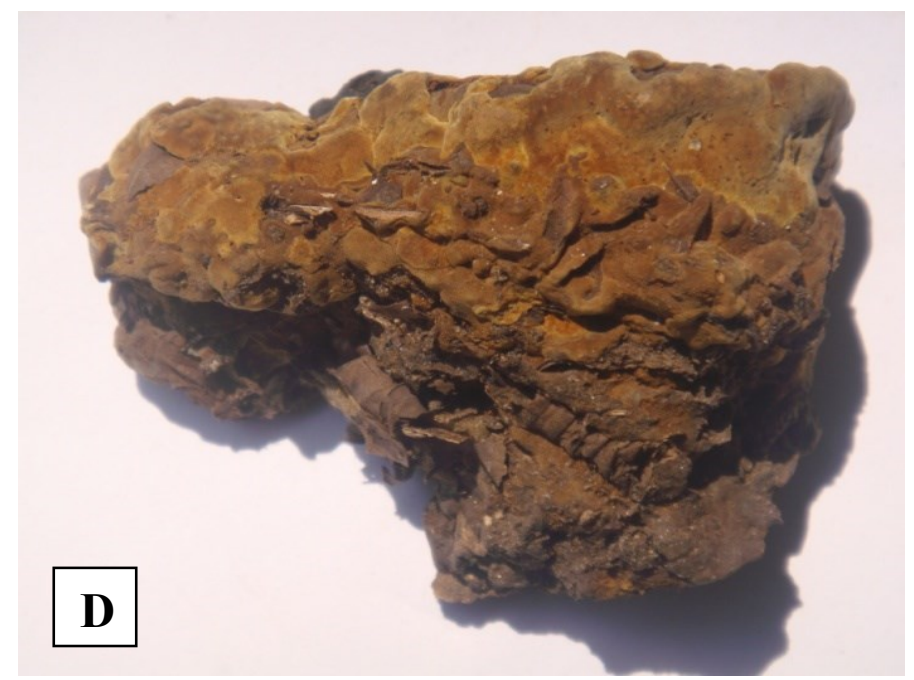

Figure III
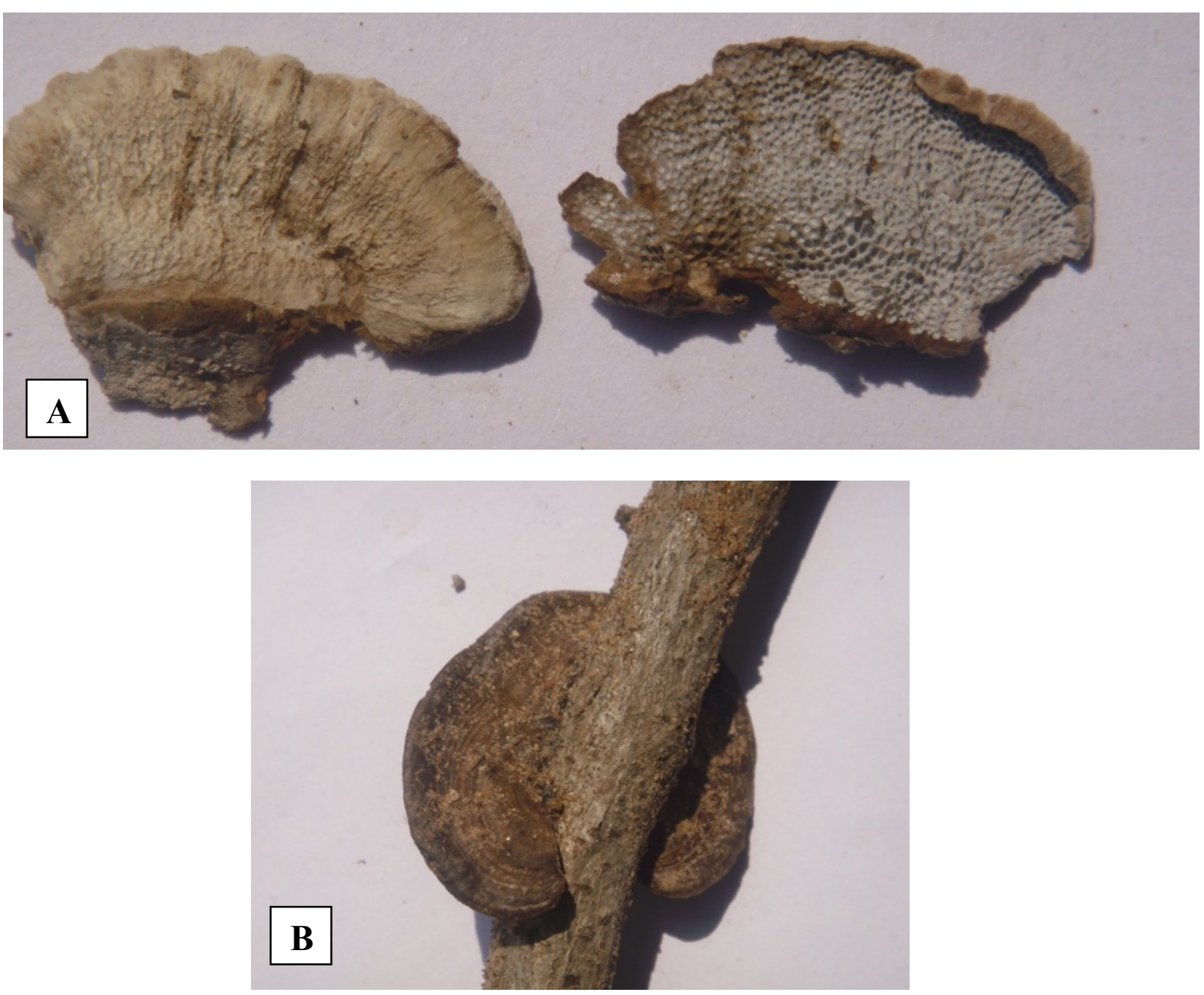

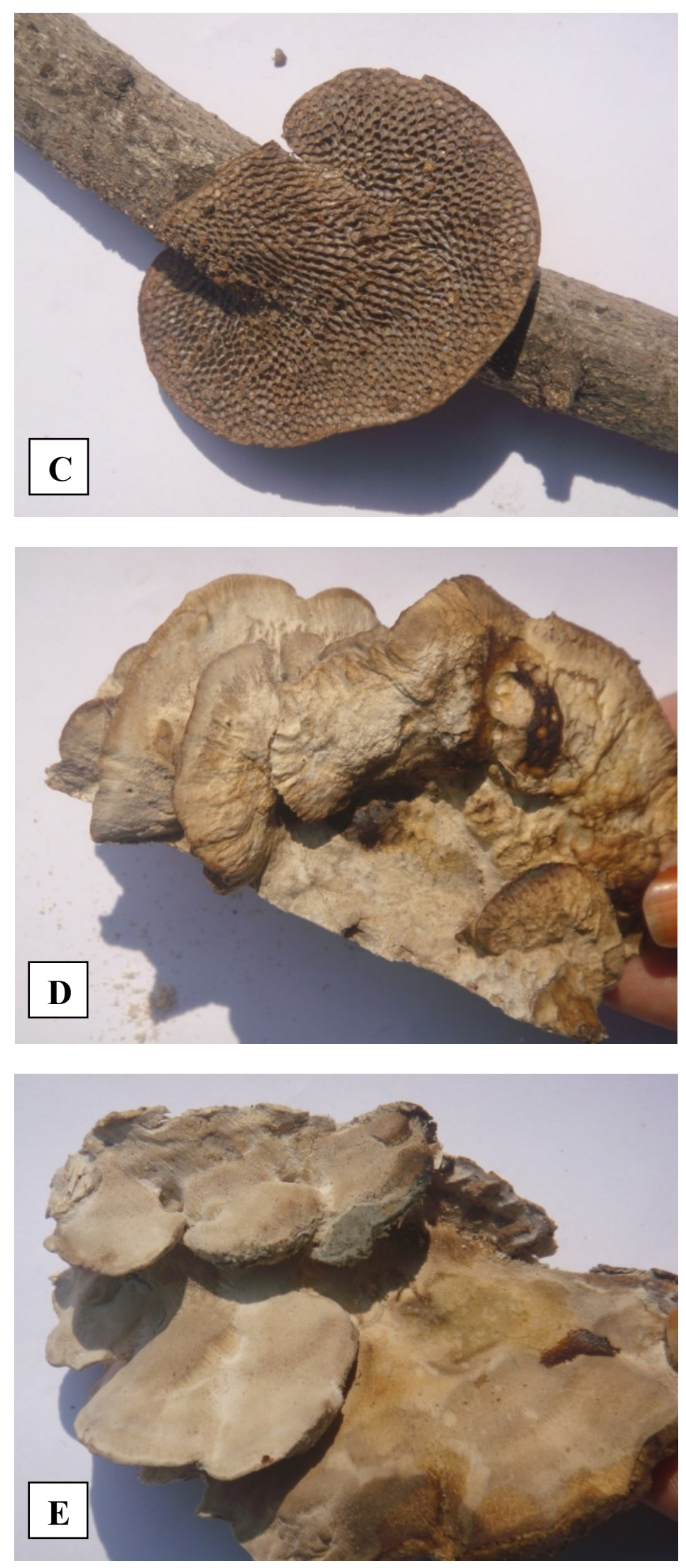


\section{CONCLUSIONS}

Lignicolous fungi include many wood decay fungi which degrades the lignin content of wood. Most of these fungal species can result in economic losses in forest and to wood users. In the present survey new and interesting records of delignifying fungi were detected in Andhra Loyola college, Vijayawada and Krishna District, Andhra Pradesh, India. Lignicolous fungi were found on living trees and fallen branches Syzygium cumini, Casurina equsitifolia, Prosopis julifera and Peltophorum from Andhra Loyola College campus. We describe the occurrence of Coriolopsis aspera (Junghuhn) Teng., Fulvifomes nilgheriensis (Montagne) Bondartseva \& S. Herrera, Ganoderma australe (Fr.) Pat., Ganoderma lucidum (Curtis) P. Karsten, Hexagonia apiaria (Pers.) Fr., Phellinus linteus (Berk. \& Curt.) Teng., Trametes cingulata Berk. Hook., T. cotonea (Pat. \& Har.) Ryv. T. gibbosa (Pers.) Fr., and Schizophyllum commune Fr. in Krishna district, Andhra Pradesh, India for the first time. Fulvifomes nilgheriensis (Montagne) Bondartseva \& S. Herrera is recorded for the first time from India.

\section{Acknowledgements}

The authors are thankful to the Head, Department of Botany, Andhra Loyola college, Vijayawada for laboratory facilities and to Dr. J. R. Sharma from Forest Research Institute Dehradun, India for conforming the identity of the fungi.

\section{Reference}

[1] K. Natarajan, K. Kolandavelu, CAS in Botany University of Madras, Chennai. (1985) pp. 133.

[2] T. K. Kirk, R. R. Burgess, J. W. Koning (1992a). Leatham G, ed. Frontiers in industrial mycology, New York, New York: Routledge, Ahapman and Hall. Pp. 99.

[3] P. K. Nagadesi, V. H. Jayaraj A. Arya, in Proceedings of National Seminar on Recent Trends in Nano-Biotechnology in the Protection of Health and Environment 30th Nov - $1^{\text {st }}$ Dec, 2012, pp 145-151, ISBN: 978-81-924726-1-4.

[4] G. Rangaswami, T. K. Kandaswami, K. Ramaswamy, Current Science 44 (1975) 403-404.

[5] A. Roy, A. B. De Int. book Dist. Dheradun (1996) pp. 309.

[6] B. K. Bakshi, Indian Council of Agricultural Research, New Delhi. (1971) pp. 246.

[7] A. Arya In: Vistas in Palaeobotany and Plant Morphology: Evolutionary and Environmental Perspectives, Prof D D Pant Memorial Vol, P C. Srivastava (ed) Published by UP Offset, Lucknow, India. (2004) pp 321-327.

[8] A. Arya, S. Albert, Journal of Mycology and Plant Pathology 38(2) (2008) 221-226.

[9] P. K. Nagadesi, A Arya, Mycosphere 3(6) (2012) 997-1003.

[10] P. K. Nagadesi, A Arya, International Letters of Natural Science 1 (2014) 1-7.

[11] P. K. Nagadesi, A. Arya International Letters of Natural Science 2 (2014) 13-22. 
[12] K. D. Bagchee, Indian Forester 76 (1950) 216-220.

[13] K. D. Bagchee. Indian Forest Records 2 (1961) 15-58.

[14] B. K. Bakshi, Indian Forester 81 (1955) 779-797.

[15] B. K. Bakshi, Published by the Controller of Publication, Delhi, 1976, pp: 55-72.

[16] P. N. Ganesh, K.M. Lcelavathy, Current Science 55 (1986) 727-728.

[17] A. Roy, Mycologia 71 (1979) 1005-1008.

[18] J. R. Sharma, Botanical Survey of India, Calcutta. 1995, pp. 291.

[19] J. R. Sharma, Botanical Survey of India, Dehradun, 1999a, pp. 169.

[20] B. Singh, Indian Forester 92 (1966) 653-655.

[21] K. S. Thind, R. S. Dhanda, Kavaka 8 (1980) 59-67.

[22] L. Ryvarden, Synopsis Fungorum Fungi flora, Oslo, 1991, pp. 363.

[23] L. Ryvarden, I. Johansen, A preliminary polypore flora of East Africa, 1980, pp. 443.

[25] L. Ryvarden, Syn. Fung. 19 (2004) 183

[26] G. H. Cunningham, Newzealand Department of Science and Industrial Research Bullet 164 (1965) 304.

[27] R. L. Steyaert, CMI Descr. Pathog. Fungi Bact. 445 (1975) 1-2.

[28] J. L. Lowe, State University College of forestry at Syracuse University, technical publication No. 80 (1957) 97. 